\title{
Mutations of the Gene for the Aryl Hydrocarbon Receptor-Interacting Protein in Pituitary Adenomas
}

\author{
Laure Cazabat ${ }^{a, b}$ Marine Guillaud-Bataille ${ }^{c}$ Jérôme Bertherat ${ }^{a, b}$ \\ Marie-Laure Raffin-Sanson ${ }^{\mathrm{a}, \mathrm{d}, \mathrm{e}}$ \\ aINSERM, U567, Département d'Endocrinologie, Métabolisme et Cancer, CNRSURM8104; Institut Cochin; \\ Université Paris V, Faculté de Médecine René Descartes; Départements ${ }^{b} \mathrm{~d}$ 'Endocrinologie et \\ 'de Biochimie Hormonale, Hôpital Cochin, Assistance Publique, Hôpitaux de Paris, Paris; \\ ${ }^{d}$ Département d'Endocrinologie, Hôpital Ambroise Paré, Assistance Publique, Hôpitaux de Paris, Boulogne; \\ and 'Université Versailles SQY, Faculté de Médecine, Paris lle de France Ouest, France
}

\section{Key Words}

Aryl hydrocarbon receptor-interacting protein gene •

Pituitary adenoma - Familial isolated pituitary adenomas . Isolated familial somatotropinomas · Acromegaly

\begin{abstract}
Heterozygous germline mutations in the gene encoding the aryl hydrocarbon receptor-interacting protein (AIP) were first described in two Finnish families with pituitary adenomas. The gene is involved in about $15 \%$ of familial isolated pituitary adenomas (FIPA), in about $50 \%$ of cases of familial acromegaly and in a small proportion of acromegalic patients with sporadic presentation. This review describes the genetic and clinical features of published patients with AIP, with either familial or sporadic pituitary tumors. A genotype-phenotype correlation is proposed: patients with AIP mutations resulting in a truncated protein are significantly younger than those bearing a mutation which preserves the structure of the C-terminal end of the protein ( $22.7 \pm 9.6 \mathrm{vs}$. $29.8 \pm 10.9$ years). Pituitary tumors linked to AIP mutations are almost exclusively somatotropic $(87.5 \%, n=56 / 64)$ or lactotropic $(9.4 \%, n=6)$. Patients with AIP mutations are mostly
\end{abstract}

men $(70 \%, 44 \mathrm{M} / 19 \mathrm{~F})$, suffer macroadenomas (97\%) and are younger at diagnosis (24.4 \pm 10.5 years) than unselected patients with pituitary tumors. Thus, AIP is involved in the development of pituitary tumors, especially involving the somatomammotroph lineage. Genetic testing could be discussed for FIPAs and in young acromegalic patients with a sporadic presentation. Functional studies are needed to understand AIP-induced tumorigenesis.

Copyright $\odot 2009$ S. Karger AG, Basel

\section{Introduction}

The pathophysiology of pituitary tumors remains largely unknown, despite recent progress in the elucidation of various genetic syndromes associated with pituitary neoplasias. Although almost always benign, these tumors cause significant morbidity in affected patients because of their secretory activities or local development or both. Their prevalence has been largely underestimated in the past with previous estimations being between 2 and 3 per 10,000. However, large autopsy series indicate a prevalence of between 6 and $22 \%$ of subclinical pitu-

\section{KARGER}

Fax +4161306 1234 E-Mail karger@karger.ch www.karger.com (c) 2009 S. Karger AG, Basel

0301-0163/09/0713-0132\$26.00/0

Accessible online at:

www.karger.com/hre
Prof. Marie-Laure Raffin-Sanson

Hôpital Ambroise Paré

FR-92240 Boulogne (France)

Tel. +331 490954 95, Fax +331 49095649

E-Mail marie-laure.raffin-sanson@apr.aphp.fr 
itary tumors (mean 14\%) [1], and pituitary MRI in healthy volunteers reveals a frequency of about $10 \%$ among pituitary abnormalities compatible with occult pituitary adenoma [2]. A recent epidemiological study of symptomatic pituitary adenomas reported an overall rate of 1 per 1,064 of the general population, which is three times higher than previously believed [3].

Each anterior pituitary cell type may undergo monoclonal proliferation. The resulting tumors are commonly classified according to their secretion pattern or to immunohistochemical staining pattern. Among clinically symptomatic pituitary adenomas, prolactinomas are the most frequent tumors ( $\approx 65 \%$ ), followed by non-secreting tumors $(\approx 15 \%)$, somatotropinomas $(\approx 13 \%)$, corticotropinomas $(\approx 6 \%)$ and thyrotropinomas $(\approx 1 \%)[3,4]$.

The large majority of these tumors are sporadic. A small proportion (about 3\%) occurs with a familial aggregation, as components of either the multiple endocrine neoplasia type 1 (MEN1) or the Carney complex (CNC), both syndromes associated with a genetic predisposition to multiple endocrine tumors $[5,6]$. Isolated familial pituitary adenomas have also been described in the absence of MEN1 and PRKAR1A mutations [7], and this situation represents about $1 \%$ of all adenomas. It appears that patients in the same families can exhibit either the same pituitary tumor type or different tumor types; it has been suggested that these clinical syndromes should be classified as homogeneous and heterogeneous familial isolated pituitary adenoma (FIPA) kindreds, respectively [8]. Recently, Vierimaa et al. [9] described germline-inactivating mutations in the gene encoding the aryl hydrocarbon receptor interacting protein (AIP) in some of these families. Individuals carrying these mutations presented with combinations of somatotropinomas, mixed GH-prolactin-secreting tumors and prolactinomas. The AIP gene maps at 11q13, in the same region as the MEN1 gene. Analysis of tumor samples from affected individuals showed loss of heterozygosity at the AIP locus suggesting that AIP acts as a tumor suppressor gene. Further studies found AIP mutations in 15\% of all FIPAs and about $50 \%$ of families presenting with only $\mathrm{GH}$-secreting tumors. AIP mutations were also found in a small number of patients with sporadic pituitary adenomas, mostly GH-secreting tumors.

This review addresses the clinical and molecular features of pituitary adenomas occurring in a familial setting or in patients presenting with sporadic tumors but bearing a germinal mutation of the AIP gene.

Mutations of the Gene for the AIP

Protein in Pituitary Adenomas

\section{Method}

We collected information about all patients with AIP mutations reported in the literature since the first description of Vierimaa et al. [9] up to March 2008. In particular the mutation, age at diagnosis, familial or sporadic presentation, tumor type, sex and tumor size (micro- or macroadenoma) for each case are reported when available [9-17]. The Mann-Whitney non-parametric test and $\chi^{2}$ Pearson test were used for statistical analysis.

\section{Genetic of Pituitary Adenomas}

Pituitary adenomas may occur as part of genetic syndromes associated with other endocrine or non-endocrine tumors. The most frequent of these syndromes is MEN1, with an estimated prevalence of $0.02-0.2$ per 1,000 . MEN1 is an autosomic dominant inherited disease predisposing to primary hyperparathyroidism, endocrine digestive tumors, pituitary adenomas and some other rare lesions. Affected patients bear an inactivating mutation of the MEN1 gene, located at chromosome $11 \mathrm{q} 13$, and the normal allele is lost in the tumors. Pituitary adenomas occur in about $40 \%$ of these patients. Pituitary tumors associated with MEN1 are more frequently diagnosed in women than in male (sex ratio 1:5), and this is also the case for non-MEN1 patients. The distribution of immunohistological types is not different from that of sporadic tumors, with two thirds of the patients presenting with prolactinomas [4]. Recently, mutations in the CDKN1B gene, located at chromosome 12p13 and encoding the p27kipl protein, were found in one family with GH-secreting pituitary adenomas and hyperparathyroidism and also in 1 patient with Cushing's disease and hyperparathyroidism. This new entity was called MENX. Other endocrine or non-endocrine tumors have been observed in patients. $\mathrm{LOH}$ has been described in a small-cell neuroendocrine cervical carcinoma and suggests that $C D K N 1 B$ may act as a tumor suppressor gene $[18,19]$. However, these mutations appear to be very rare among patients with MEN1 phenotype and a normal MEN1 sequence [18, 20].

Activating mutations of the GNAS 1 gene, located at chromosome $20 \mathrm{q1} 3$ and encoding the $\alpha$ subunit of protein Gs ( $g s p$ oncogene), are responsible for the McCuneAlbright syndrome (MAS). These mutations can be found in different tissues (mosaicism) resulting from a post-zygotic event. The same mutation is found in about $40 \%$ of sporadic somatotropinomas. 
MAS affects various tissues through activation of the cAMP pathway. Café-au-lait spots, fibrous osteodysplasia and endocrine hyperactivity (leading to precocious puberty, GH excess, hyperthyroidism and other manifestations) are the main clinical features [21]. In the same cellular pathway, inactivating mutations in the gene encoding the regulatory subunit $\mathrm{R} 1 \alpha$ of the protein kinase A (PRKAR1A), located at 17q22-24, have been described in CNC. Patients present with myxomas, spotty skin pigmentation (lentigines) and endocrine overactivity including primary pigmented nodular adrenocortical disease (PPNAD) responsible for adrenocorticotropic hormone-independent Cushing syndrome. GNAS-activating mutations increase cAMP levels in tissues [22], and PRKAR1A-inactivating mutations result in abnormal PKA activity [23]. In cases of MAS and CNC, the pituitary gland frequently shows somatomammotrope hyperplasia with high growth hormone and IGF-I levels and mild hyperprolactinemia, whereas somatotropinomas or somatomammotrope adenomas are much less common [24,25]. In contrast to GNAS mutations, somatic mutations of PRKAR1A and MEN1 are uncommon in sporadic pituitary tumors [26, 27].

$M E N 1, P R K A R 1 A$ and extremely rarely $C D K N 1 B$ may be involved in familial syndromes associating pituitary adenomas and other tumors; in contrast, germline mutations in the AIP gene have been described in FIPA [9]. AIP mutations have been found in $15-20 \%$ of FIPAs (20 families). Families with AIP mutations mostly have IFS (isolated familial somatotropinomas) (15/20) or are families with lactotropinomas and somatotropinomas (4/20). So, germline mutations of AIP predispose to the development of tumors secreting $\mathrm{GH}$ or both $\mathrm{GH}$ and prolactin, reminiscent of the pituitary phenotype of pathologies linked to the cAMP pathway (MAS and CNC).

$\mathrm{LOH}$ of at the AIP gene has been demonstrated in tumors from mutated patients, supporting the hypothesis of a tumor suppressor gene mechanism. Many relatives of affected subjects are asymptomatic carriers suggesting that the disease has a low penetrance.

\section{AIP Protein}

AIP, also called aryl hydrocarbon receptor-associated protein 9 (ARA9), has been known for more than 10 years as a protein associated with the aryl hydrocarbon receptor (AHR), a ligand-inducible transcription factor that mediates the cellular response to xenobiotic compounds including various environmental pollutants [28]. In the absence of ligand, the latent receptor is associated with the $90-\mathrm{kDa}$ heat-shock protein (HSP90, a molecular chaperone) and AIP [28]. Upon ligand binding, AHR accumulates in the nucleus where it forms a transcriptionally active complex. Activation of the AHR-mediated signaling pathway by xenobiotic compounds has numerous toxic effects, including carcinogenesis, teratogenesis, and immunosuppression. AIP, in turn, stabilizes the AHR protein and participates in the regulation of the intracellular localization of the receptor by a cytoplasmic retention mechanism that has not yet been described.

Simultaneously, AIP was found to interact with the hepatitis B virus X-protein, and was therefore also called hepatitis B virus X-associated protein (XAP2) [29]. More recently, Sumanasekera et al. [30] demonstrated that AIP can also bind another xenobiotic receptor, PPAR $\alpha$ (peroxisome proliferator activated receptor $\alpha$ ).

AIP is a 330 -amino-acid protein belonging to the immunophilin family. It is made up of two domains: the $\mathrm{N}$ terminal FKBP domain and the C-terminal domain containing three tetratricopeptide repeats domains (TPRs). The TPRs region is responsible for protein-protein interactions: this part of AIP binds HSP90 and other regulatory proteins [31]. The five last amino acids of the $\alpha$-helical C-terminus of AIP, outside the TRPs domain, are absolutely required for binding to AHR; deletion and mutagenesis studies show that all AIP mutations leading to C-terminal truncated proteins or lacking one of these five amino acids are unable to interact with AHR [32]. The AIP N-terminal domain contributes to the stability of the AHR-HSP90-AIP complex and the regulation of its intracellular localization.

The TPRs region is responsible for protein-protein interactions and this part of AIP binds both HSP90 and also phosphodiesterases. Interaction with AIP decreases the activity of the cAMP-specific phosphodiesterase PDE4A5 [33], whereas the binding of PDE2A to AIP inhibits the nuclear translocation of the AHR complex possibly by a local reduction of the cAMP levels [34]. Moreover, the AHR pathway may be activated by cAMP, in a way that appears different from AHR activation by dioxin. Disruption of the physiological cAMP-mediated activation of AHR by xenobiotic compounds has been proposed to be an important mechanism in their toxicity [35]. These possible links between AHR signal transduction and cAMP are obviously of potential significance to endocrine tumorigenesis, especially in mammosomatotrope cells.

AIP is also associated with survivin and regulates its stability [36]; it also interacts with ubiquitin ligase protein C-terminal Hsp70-interacting protein (CHIP) and protects AHR from CHIP-mediated degradation [37]. 
Table 1. AIP germline mutations and their putative consequences

\begin{tabular}{|c|c|c|c|c|}
\hline Mutation & Nucleotide & Putative protein & $\mathrm{n}$ & Ref. \\
\hline \multicolumn{5}{|l|}{ C-terminus truncated } \\
\hline \multirow[t]{8}{*}{ Nonsense } & c. $40 \mathrm{C}>\mathrm{T}$ & p.Gln $14 \mathrm{X}$ & 17 & 9 \\
\hline & c. $64 \mathrm{C}>\mathrm{T}$ & p.Arg22X & 1 & 10 \\
\hline & c. $424 \mathrm{C}>\mathrm{T}$ & p.Q142X & 1 & 12 \\
\hline & c. $601 \mathrm{~A}>\mathrm{T}$ & p.Lys201X & 2 & 11 \\
\hline & c. $649 \mathrm{C}>\mathrm{T}$ & p.Q217X & 2 & 12 \\
\hline & c. $715 \mathrm{C}>\mathrm{T}$ & p.Q239X & 2 & 12 \\
\hline & c. $804 \mathrm{~A}>\mathrm{C}$ & p.Y268X & 2 & 17 \\
\hline & c. $910 \mathrm{C}>\mathrm{T}$ & p.Arg304X & 6 & $9,11,12$ \\
\hline \multirow[t]{6}{*}{ Frameshift } & c.286-287delGT & p.Val96Pro.fsX31 & 3 & 14 \\
\hline & c.404delA & p.His135Leu.fs19X & 1 & 11 \\
\hline & c.517-521delGAAGA & p.Gln174Gly.fs $22 X$ & 3 & 15 \\
\hline & c.542delT & p.I182S.fsX12 & 1 & 13 \\
\hline & c.824-825insA & p.His $275 \mathrm{Gln} \mathrm{X} 13$ & 1 & 13 \\
\hline & c.854-857delAGGC & p.Gln285fsX18 & 2 & 12 \\
\hline \multicolumn{5}{|l|}{ C-terminus conserved } \\
\hline \multirow[t]{3}{*}{ Splicing site } & IVS2-1 G>C & & 1 & 13 \\
\hline & c. $469-2$ A $>G$ & & 1 & 11 \\
\hline & c. $469-1 \mathrm{G}>\mathrm{A}$ & & 1 & 9 \\
\hline \multirow[t]{2}{*}{ Deletion } & c.66-71delAGGAGA & p.del23-24 & 1 & 13 \\
\hline & c. $138-161 \mathrm{del} 24$ & p.del47-54 & 2 & 12 \\
\hline Deletion and missense & $\begin{array}{l}\text { c.878-879 AG }>\text { GT and } \\
\text { c.880-891 delCTGGACCCAGCC }\end{array}$ & $\begin{array}{l}\text { p.Glu293Gly,Leu294- } \\
\text { Ala297del }\end{array}$ & 1 & 13 \\
\hline \multirow[t]{3}{*}{ Missense } & c. $721 \mathrm{~A}>\mathrm{G}$ & p.Lys241Gln & 2 & 12 \\
\hline & c. $811 \mathrm{C}>\mathrm{T}$ & p.R271W & 4 & 12 \\
\hline & c. $911 \mathrm{G}>\mathrm{A}$ & p.Arg304Gln & 3 & 11,13 \\
\hline
\end{tabular}

Lin et al. [38] recently suggested that AIP may interact with pathways other than xenobiotic receptor signal transduction, at least in mice. Ara9-/- mice (AIP-/-) display embryonic lethality and cardiac deformations. The phenotype is different from those of Ahr-/- or Ppar $\mathrm{Al} /$ mice. No pituitary abnormalities have been described in heterozygotes $(A I P+/-)$ mice, but long-term follow-up of these animals is required. In view of the lethality of the AIP-/- genotype, pituitary-specific AIP knock-down mice may well be more informative.

The role of AIP in tumorigenesis in pituitary and more specifically mammosomatotrope cells is still largely unknown. Functional studies and work with animal models in the future should help resolve this issue.

\section{AIP Mutations in Pituitary Tumors}

In May 2006, Vierimaa et al. [9] described the first germline AIP mutations in FIPA in two Finnish families presenting prolactinomas and somatotropinomas, and in some sporadic patients with acromegaly. They performed whole-genome single-nucleotide polymorphism studies and linkage analysis in these families and found the region 11q12-11q13. This region contains the MEN1 gene and was already implicated in familial acromegaly, without MEN1 mutation [39]. The authors looked at expression profiles of genes in this region in lymphocytes of patients with familial pituitary tumor: AIP was underexpressed compared with the other genes. They then sequenced the coding region of $A I P$ and detected a heterozygous nonsense germline mutation segregating with pituitary adenoma; tumoral DNA analysis showed $\mathrm{LOH}$ suggesting a tumor suppressor gene.

Now, about 25 different germline mutations have been reported in patients with pituitary adenomas [9-15, 17] (table 1). No somatic mutations of the AIP gene in pituitary adenomas have yet been reported, but only one published study has looked for AIP mutations in tumoral DNA [10].

The first described AIP mutation, p.Gln14X, has only been observed in the Finnish population and results from 


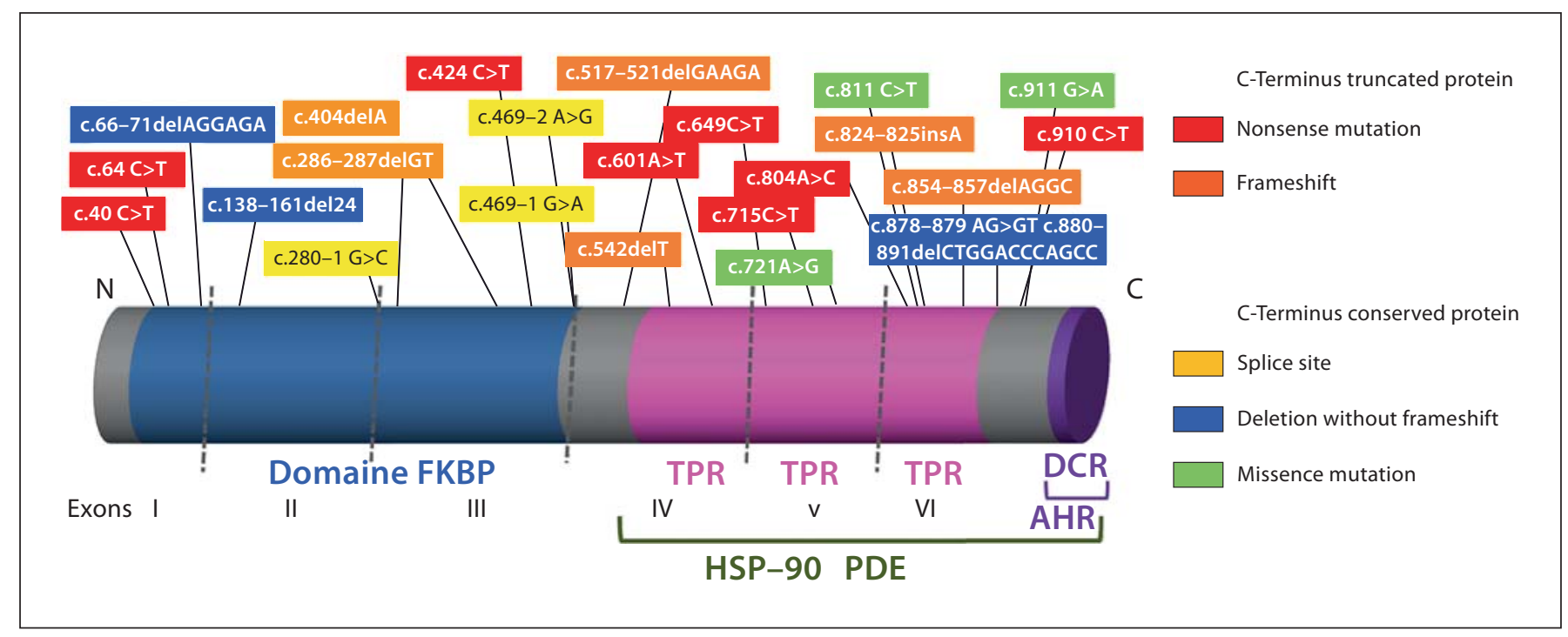

Fig. 1. AIP structure and published mutations. This figure represents functional domains of AIP with different colors: the N-terminal part (NFKBP domain) in blue, and the C-terminal part comprising the three tetratricopeptide repeat (TPR) domains in pink, and the distal C region (DCR) in purple. The C-terminus of the protein binds the aryl hydrocarbon receptor (AHR); the region interacting with the 90-kDa heat-shock protein (HSP90) and phosphodiesterases (PDE) is shown in green. The mutations listed in table 1 are indicated; legends for the symbols are presented beside the figure.

a founder effect; the first two Finnish families described have a common ancestor [40]. In this population, a few patients with the same AIP mutation present with sporadic prolactinomas $[9,16]$. A high frequency of AIP mutation is thus observed in Finnish acromegalic patients (16\%) [40], and especially in the youngest subjects (40\%) [9].

Among the non-synonymous amino acid changes in the AIP protein in patients, three might be rare polymorphisms: the p.Ala299Val [11, 13], p.Val49Met [14], and p.Arg16His [11-13, 41] substitutions [13, 41]. More studies are needed to compare the frequency of these variants between patients and matched controls and to test the functional consequences of the mutant protein. We excluded the patients with these three AIP variants from subsequent analysis.

Most known mutations in the AIP gene result in a truncated protein, lacking more or less of the C-terminal sequences important for protein-protein interactions (TPRs); in all cases, the last five amino acids essential for AHR binding are missing. Eight different nonsense mutations and six different frameshift mutations have been described, leading to premature stop codons distributed all along the coding sequence. Other mutations include splice site mutations and deletions not resulting in frameshifts and a few missense mutations. Splice site mutations involving exons 3 and 4 (two exons with a number of nucleotides divisible by three: 189 and 177, respectively) probably result in exon skipping without frameshift. The c.469-2 A>G mutation leads to an mRNA with deletion of exon 4 [pers. data]. The mutant protein lacks important central regions, as exon 3 encodes a large part of the FKBP-PPI domain and exon 4 encodes the whole first TPR domain, but it retains an intact C-terminal end. Deletions within the coding sequence, not resulting in frameshifts or premature stop codons, would have the same effects. All the known missense mutations map in the C-terminal part of the protein, necessary for proteinprotein interactions; the substitution of the arginine at position 271 (a mutation present in two FIPA families) reduces the interaction of AIP with PDE4A5 [33]. However, these mutations result in a protein with a conserved $\alpha$-helical C-terminus, the structure required for AHR binding (fig. 1).

We compared the phenotypes of the patients bearing the two types of mutations: those resulting in truncated proteins lacking the C-terminal domain and those keeping an intact or generally conserved C-terminus. Patients in the first group are significantly younger $(22.7 \pm 1.4 \mathrm{vs}$. $29.8 \pm 2.8$ years, mean \pm SEM, $p<0.05$ ) (fig. 2). They are (not significantly) more frequently diagnosed in 
FIPAs than with a sporadic presentation: $37 / 46$ (80\%) versus $12 / 19$ (63\%). Thus, mutations with roughly conserved C-terminus may be less pathogenic such that age at diagnosis is significantly older; they may also have lower penetrance that could explain the more frequently sporadic presentation. However, this possibility needs confirmation in larger cohorts and by functional analyses that are not yet available.

Concerning tumor secretion, statistically valid genotype/phenotype studies are not possible, because of the small numbers of AIP-mutated patients presenting with non-GH-, non-PRL-secreting adenomas. Note, however, that both the only family with AIP mutation and without somatotropinoma and the only patient with sporadic presentation with neither somatotropinoma nor prolactinoma (Cushing's disease) have missense mutations (p.Lys 241Gln and p.Arg304Gln, respectively).

\section{Clinical Presentation of AIP-Mutated Patients}

64 patients with pituitary adenoma and a germline AIP mutation have been reported in the literature: 45 with a familial history and 19 with a sporadic presentation (30\%). Analysis of the data concerning these patients provides some important clues and raises new questions.

\section{What Is the Frequency of AIP Mutations among}

Patients with Pituitary Adenoma Occurring in a

Familial Setting?

AIP analysis demonstrated an overall frequency of AIP mutations of $15 \%$ among FIPAs and of $50 \%$ among cohorts with IFS [12]. Thus, AIP mutations are mostly found in families with exclusively GH-secreting adenomas or somatotropinomas and prolactinomas, but can explain only half of such cases. Among families only including prolactinomas or families comprising non-secreting/gonadotroph adenomas or corticotroph adenomas, AIP mutations appear to be very rare. The age of patients in homogeneous families with acromegaly and that of patients in heterogeneous families with GH and PRL adenomas is similar (22.6 \pm 7.2 and $19.6 \pm 6.6$ years, respectively); patients from the only family with non-secreting adenoma and prolactinoma are older (45 and 53 years of age) (fig. 3 ).

\section{What Type of Secretion Is Associated with AIP Mutation?}

In unselected familial pituitary adenomas, prolactinomas are generally more frequent $(41 \%$ among FIPA cohorts) than somatotropinomas or somatolactotropino-

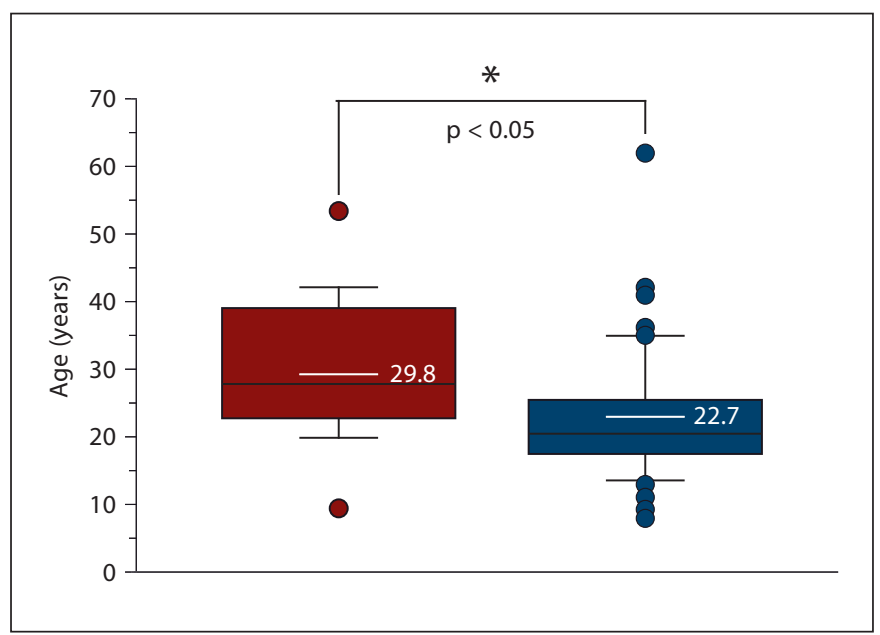

Fig. 2. Age at diagnosis in the patients according to the type of AIP mutation. The horizontal lines are the medians; the rectangles represent the interquartile range $(50 \%$ of patients in the center of the distribution), the vertical lines are the adjacent values and atypical values are visualized by dots. The means are represented by white lines and their values are indicated alongside.

mas (30 and 7\% of pituitary tumors occurring in a familial context) [42]. Most cases of FIPA with AIP mutation involve somatotropinomas ( $82 \%$ and up to $86 \%$ if somatolactotrope adenomas are included (39 of 45 cases)). Prolactinomas are present in only $11 \%(n=5)$ of patients in FIPA with AIP mutation. Non-secreting/gonadotrope adenomas and corticotrope adenomas are extremely rare in cases of FIPA with AIP mutation [8]. The only reported familial case of non-secreting adenoma with AIP mutation is associated with a prolactinoma. With the exception of this case, all FIPA families with AIP mutation present with familial GH-secreting tumors in some cases associated with prolactinomas.

Among patients with AIP mutation and sporadic presentation, there is also a large majority of somatotropinomas $(84 \%, n=16 / 19)$ and only one case each of somatolactotropinoma, prolactinoma, and corticotroph adenoma.

What Is the Frequency of AIP Mutations in Patients with Apparently Sporadic Pituitary Adenomas?

AIP mutations are rare in unselected patients with sporadic acromegaly, with reported frequencies ranging from $0[14,16]$ through $3-4 \%$ in the largest cohorts $[11,13]$ and up to $16 \%$ in Finland [40]. The true frequency is unfortunately not available in some cohorts in which sequence analysis of the AIP gene has been limited to the three first 


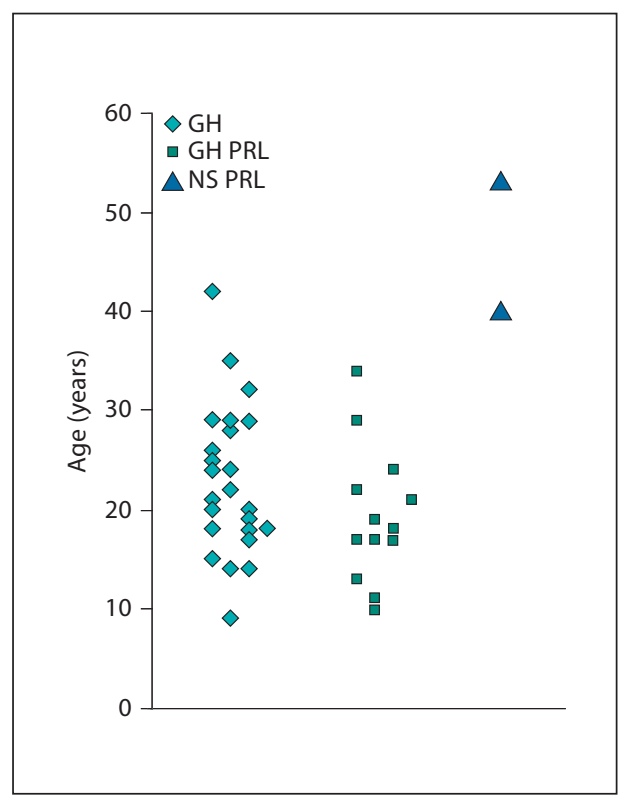

Fig. 3. Distribution of tumor phenotype in AIP-mutated patients with either familial (FIPA) or sporadic presentation. This figure shows the ages of all published FIPA patients with AIP mutation classified into three groups: IFS patients in red $(\mathrm{GH})$, subjects with heterogeneous FIPA with prolactinomas and somatotropinomas in purple (GH PRL), and the 2 patients from the heterogeneous FIPA with a non-secreting tumor (NS) and a prolactinoma $(\mathrm{PRL})$ in orange.

mutations described $[43,44]$. In young acromegalic patients, however $(<25$ or $<30$ years of age according to the study), AIP mutations have been observed in about 10 $15 \%[11,13]$. In patients with other types of sporadic adenomas, AIP mutations are very rarely reported ( 1 in 86 cases of Cushing disease, none of 76 non-secreting adenomas), whereas prolactinomas have been described only in the Finnish population $[13,16]$. However, few systematic studies are available and consequently additional investigations are required, particularly for young patients.

What Is the Penetrance of Pituitary (or Non-Pituitary) Disease in Patients with an AIP Mutation Diagnosed by Genetic Screening?

So far, data are scare concerning relatives of patients with sporadic presentation. In our experience in a cohort of apparently sporadic acromegalic patients, no de novo mutation has been observed (in all cases, one of the parents carried the mutation). Thus, the sporadic presentation is likely a result of low penetrance of the disease. The mutated first-degree relatives are clinically asymptomatic (three families) [unpubl. data] and complete clinical,

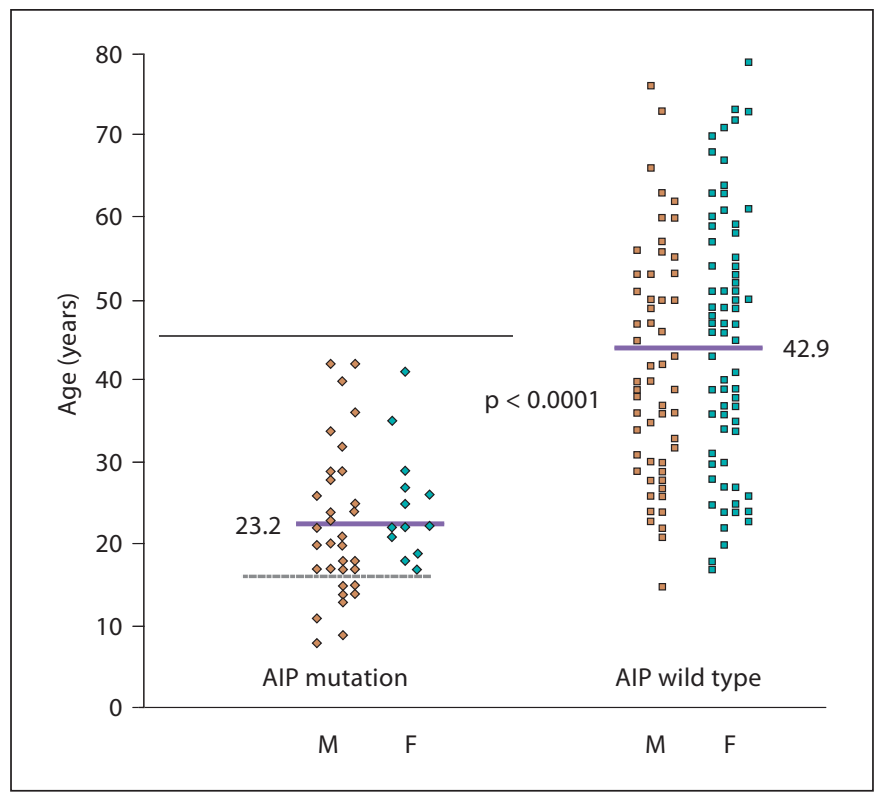

Fig. 4. Age, sex and AIP status of cases of sporadic acromegaly. This graph represents the sex and age at diagnosis of acromegalic patients with or without AIP mutation [9-11, 13]. All mutated patients are $<45$ years of age (gray line). All mutated patients $<17$ years of age are male (gray dotted line). On the right is a French cohort of acromegalic patients with normal AIP sequence [11]. Mean age at diagnosis for each group is indicated with a green line and the values are indicated alongside.

hormonal and morphological analysis would be informative. The penetrance of pituitary disease in patients with AIP mutations has been studied in a few families $[8,15$, 17]. In two extensively explored families, $30-50 \%$ of clinically asymptomatic mutation carriers have isolated increased levels of IGF1 or prolactin with normal pituitary MRI findings $[8,15,17]$. However, these percentages are based on very preliminary investigations. Extrapituitary disorders related to AIP mutation could be suspected because of the non-endocrine specificity of AIP expression. Available descriptions of patients lack complete clinical data and rare extrapituitary disease cannot be excluded. Note that a 2-year-old child with AIP mutation presents a premature thelarche [15].

\section{Are There Particularities in the Presentation of the Pituitary Disease in Patients Bearing an AIP Mutation?}

In unselected FIPA cohorts, women are in the majority (62\%), whereas cases in FIPA kindreds with AIP mutation are mostly men $(71 \%, 32 \mathrm{M} / 13 \mathrm{~F})$, as described for IFS [45]. As expected, patients with sporadic presenta- 
tion and AIP mutation are similarly mostly men $(67 \%, 12$ $\mathrm{M} / 6 \mathrm{~F}$ ). Women with AIP mutation tend to be older at diagnosis than men $(26.7 \pm 9.4$ vs. $23.4 \pm 11$ years, respectively, NS) and gigantism has only been described in men, but clinical information is frequently missing from reports.

Patients with sporadic presentation tend to be older than patients from families $(28.5 \pm 2.8 \mathrm{n}=19$ vs. $22.6 \pm$ 1.4 years $n=41$, respectively, $\mathrm{p}<0.05$ ).

We compared the characteristics of all acromegalic patients with AIP mutation reported in the literature $(n=57)$ with the characteristics of a French cohort of apparently sporadic acromegalic patients $(\mathrm{n}=155)$ in which AIP mutation had been excluded. We are aware that this comparison introduces a bias because it incorporates two variables simultaneously: the presence or absence of the mutation, and also two different populations (patients of various origins and a French cohort). As expected, age at diagnosis was significantly younger for mutated patients $(23.2 \pm 8.1$ vs. $42.9 \pm 14.1$ years, $\mathrm{p}<$ 0.0001 ) and there was a significant male preponderance among mutated patients $(38 \mathrm{M} / 15 \mathrm{~F}$ vs. $70 \mathrm{M} / 85 \mathrm{~F}, \mathrm{p}<$ $0.001)$; all acromegalic patients with AIP mutations and $<17$ years of age are male (fig. 4).

In patients with AIP mutation, tumors are almost exclusively macroadenoma $(97 \%, 37 / 38$ with information available), whereas they represent $80.1 \%$ in the French control cohort of acromegalic patients $(p=0.01)$. However, patients with AIP mutations are younger and the frequency of macroadenoma is not significantly different from that in age-matched controls.

More detailed clinical descriptions of patients with AIP mutation are needed to assess tumor invasiveness, and in particular comparisons between these patients and other acromegalic subjects; few publications provide such information.

\section{Conclusion}

The study of pituitary adenomas as a part of hereditary syndromes brings additional elements to our understanding of pituitary tumorigenesis. The identification of menin and PRKAR1A are examples of such advances. More recently, the description of AIP mutations in FIPAs has opened up new fields of investigation. Although the relevance of the cAMP pathway remains obvious in the physiopathology of GH-secreting tumors, the unexpected involvement of a protein interacting with the AHR provided insight into the interrelation between various intracellular signaling pathways. Future work will reveal whether loss of AIP function alters the CAMP pathway or if other molecular mechanisms lead to proliferation of pituitary cells. The possible role of environmental pollutants in pituitary tumorigenesis also deserves further investigation.

AIP mutations may predispose to non-pituitary tumors. Possible missense mutations were found in patients with colic cancer, and premature pubarche has been observed in one girl with an AIP-inactivating mutation. Careful analysis of families may reveal further different diseases. Determining the complete phenotype of animal models could help, although the AHR system in rodents is somewhat different from that in man.

It would also be informative to conduct functional analysis and other investigations of $A I P$ variants not clearly associated with AIP dysfunction (missense mutations, neutral polymorphisms and sequence variants possibly associated with low penetrance predisposition).

Appropriate clinical management remains the ultimate goal. Molecular studies should be oriented by careful analysis of patient phenotype, hormonal results, pituitary MRI and family history.

Screening for $A I P$ mutations in patients with any type of pituitary adenoma occurring in a familial setting is certainly warranted because of the high frequency of AIP mutations in this situation; possibly, IFS and GH-PRL families should be targeted first. Investigations of MEN1 should remain the first line of screening in the evaluation of families without mammosomatotrope tumor.

Indications for genetic screening for AIP mutations in patients with apparently sporadic pituitary tumors require careful consideration, and some questions have yet to be resolved.

AIP mutations in patients with unselected, apparently sporadic, acromegaly are rare, from 0 to $3-4 \%$ depending on the study, and except in the Finish population where the frequency is $16 \%$; thus, systematic screening is probably not justified. However, the frequency of germline AIP mutations is higher in young patients with GH-secreting macroadenomas (about $10-15 \%$ in patients $<30$ years). Therefore, and until further studies are available in large cohorts of well-characterized patients, genetic testing of apparently sporadic acromegalic patients $<40$ years of age seems reasonable.

Should clinically asymptomatic relatives of AIP-mutated patients be screened? Until now, consequences of bearing the AIP mutation for asymptomatic subjects are not well known. So, although genetic screening of firstdegree relatives would be useful to improve our under- 
standing, and potentially beneficial for these subjects, they must be given all available information and provide informed consent prior to testing. Hormonal evaluation in asymptomatic subjects bearing the mutation may include plasma prolactin and IGF1 measurement, GH/ HGPO and pituitary MRI.

More clinical and functional studies are needed to determine the pathogenic potential of rare AIP variants and elucidate the mechanism of cellular proliferation associated with AIP disruption. Such work is worthwhile be- cause the understanding of this new molecular pathway may allow the development of new therapeutic tools for these patients with aggressive pituitary tumors, some poorly responsive to standard treatments.

\section{Acknowledgements}

This work was supported by the Plan Hospitalier de Recherche Clinique (AOR01093). We are very grateful to Sebastien Czernichow for his help with statistical analysis.

\section{References}

$\checkmark 1$ Ezzat S, Asa SL, Couldwell WT, Barr CE, Dodge WE, Vance ML, McCutcheon IE: The prevalence of pituitary adenomas: a systematic review. Cancer 2004;101:613-619.

-2 Hall WA, Luciano MG, Doppman JL, Patronas NJ, Oldfield EH: Pituitary magnetic resonance imaging in normal human volunteers: occult adenomas in the general population. Ann Intern Med 1994;120:817820.

-3 Daly AF, Rixhon M, Adam C, Dempegioti A, Tichomirowa MA, Beckers A: High prevalence of pituitary adenomas: a cross-sectional study in the province of Liege, Belgium. J Clin Endocrinol Metab 2006;91:4769-4775.

- 4 Verges B, Boureille F, Goudet P, Murat A, Beckers A, Sassolas G, Cougard P, Chambe B, Montvernay C, Calender A: Pituitary disease in MEN type 1 (MEN1): data from the France-Belgium MEN1 multicenter study. J Clin Endocrinol Metab 2002;87:457-465.

5 Bertherat J: Carney complex (CNC). Orphanet J Rare Dis 2006;1:21.

-6 Chandrasekharappa SC, Guru SC, Manickam P, Olufemi SE, Collins FS, Emmert-Buck MR, Debelenko LV, Zhuang Z, Lubensky IA, Liotta LA, Crabtree JS, Wang Y, Roe BA, Weisemann J, Boguski MS, Agarwal SK, Kester MB, Kim YS, Heppner C, Dong Q, Spiegel AM, Burns AL, Marx SJ: Positional cloning of the gene for multiple endocrine neoplasia-type 1. Science 1997;276:404-407.

7 Daly AF, Jaffrain-Rea ML, Beckers A: Clinical and genetic features of familial pituitary adenomas. Horm Metab Res 2005;37:347-354.

-8 Beckers A, Daly AF: The clinical, pathologi$\mathrm{cal}$, and genetic features of familial isolated pituitary adenomas. Eur J Endocrinol 2007; 157:371-382.

-9 Vierimaa O, Georgitsi M, Lehtonen R, Vahteristo P, Kokko A, Raitila A, Tuppurainen K, Ebeling TM, Salmela PI, Paschke R, Gundogdu S, De Menis E, Makinen MJ, Launonen V, Karhu A, Aaltonen LA: Pituitary adenoma predisposition caused by germline mutations in the AIP gene. Science 2006;312: $1228-1230$.
0 Barlier A, Vanbellinghen JF, Daly AF, Silvy M, Jaffrain-Rea ML, Trouillas J, Tamagno G, Cazabat L, Bours V, Brue T, Enjalbert A, Beckers A: Mutations in the aryl hydrocarbon receptor interacting protein gene are not highly prevalent among subjects with sporadic pituitary adenomas. J Clin Endocrinol Metab 2007;92:1952-1955.

11 Cazabat L, Libe R, Perlemoine K, ReneCorail F, Burnichon N, Gimenez-Roqueplo AP, Dupasquier-Fediaevsky L, Bertagna X, Clauser E, Chanson P, Bertherat J, RaffinSanson ML: Germline-inactivating mutations of the aryl hydrocarbon receptor-interacting protein gene in a large cohort of sporadic acromegaly: mutations are found in a subset of young patients with macroadenomas. Eur J Endocrinol 2007;157:1-8.

12 Daly AF, Vanbellinghen JF, Khoo SK, Jaffrain-Rea ML, Naves LA, Guitelman MA, Murat A, Emy P, Gimenez-Roqueplo AP, Tamburrano G, Raverot G, Barlier A, De Herder W, Penfornis A, Ciccarelli E, Estour B, Lecomte P, Gatta B, Chabre O, Sabate MI, Bertagna X, Garcia Basavilbaso N, Stalldecker G, Colao A, Ferolla P, Wemeau JL, Caron P, Sadoul JL, Oneto A, Archambeaud F, Calender A, Sinilnikova O, Montanana CF, Cavagnini F, Hana V, Solano A, Delettieres D, Luccio-Camelo DC, Basso A, Rohmer V, Brue T, Bours V, Teh BT, Beckers A: Aryl hydrocarbon receptor-interacting protein gene mutations in familial isolated pituitary adenomas: analysis in 73 families. J Clin Endocrinol Metab 2007;92:18911896.

13 Georgitsi M, Raitila A, Karhu A, Tuppurainen K, Makinen MJ, Vierimaa O, Paschke R, Saeger W, van der Luijt RB, Sane T, Robledo M, De Menis E, Weil RJ, Wasik A, Zielinski G, Lucewicz O, Lubinski J, Launonen V, Vahteristo P, Aaltonen LA: Molecular diagnosis of pituitary adenoma predisposition caused by aryl hydrocarbon receptor-interacting protein gene mutations. Proc Natl Acad Sci USA 2007;104:4101-4105.
14 Iwata T, Yamada S, Mizusawa N, Golam HM, Sano T, Yoshimoto K: The aryl hydrocarbon receptor-interacting protein gene is rarely mutated in sporadic GH-secreting adenomas. Clin Endocrinol (Oxf) 2007;66:499502 .

15 Naves LA, Daly AF, Vanbellinghen JF, Casulari LA, Spilioti C, Magalhaes AV, Azevedo MF, Giacomini LA, Nascimento PP, Nunes RO, Rosa JW, Jaffrain-Rea ML, Bours V, Beckers A: Variable pathological and clinical features of a large Brazilian family harboring a mutation in the aryl hydrocarbon receptorinteracting protein gene. Eur J Endocrinol 2007;157:383-391.

16 Raitila A, Georgitsi M, Karhu A, Tuppurainen K, Makinen MJ, Birkenkamp-Demtroder K, Salmenkivi K, Orntoft TF, Arola J, Launonen V, Vahteristo P, Aaltonen LA: No evidence of somatic aryl hydrocarbon receptor interacting protein mutations in sporadic endocrine neoplasia. Endocr Relat Cancer 2007;14:901-906.

17 Toledo RA, Lourenco DM Jr, Liberman B, Cunha-Neto MB, Cavalcanti MG, Moyses CB, Toledo SP, Dahia PL: Germline mutation in the aryl hydrocarbon receptor interacting protein gene in familial somatotropinoma. J Clin Endocrinol Metab 2007;92:1934-1937.

18 Georgitsi M, Raitila A, Karhu A, van der Luijt RB, Aalfs CM, Sane T, Vierimaa O, Makinen MJ, Tuppurainen K, Paschke R, Gimm O, Koch CA, Gundogdu S, Lucassen A, Tischkowitz M, Izatt L, Aylwin S, Bano G, Hodgson S, De Menis E, Launonen V, Vahteristo P, Aaltonen LA: Germline CDKN1B/ p27Kip1 mutation in multiple endocrine neoplasia. J Clin Endocrinol Metab 2007;92: 3321-3325.

19 Pellegata NS, Quintanilla-Martinez L, Siggelkow H, Samson E, Bink K, Hofler H, Fend F, Graw J, Atkinson MJ: Germ-line mutations in p27Kip1 cause a multiple endocrine neoplasia syndrome in rats and humans. Proc Natl Acad Sci USA 2006; 103:1555815563. 
-20 Ozawa A, Agarwal SK, Mateo CM, Burns AL, Rice TS, Kennedy PA, Quigley CM, SimondsWF, Weinstein LS, Chandrasekharappa SC, Collins FS, Spiegel AM, Marx SJ: The parathyroid/pituitary variant of multiple endocrine neoplasia type 1 usually has causes other than p27Kip1 mutations. J Clin Endocrinol Metab 2007;92:1948-1951.

-21 Akintoye SO, Chebli C, Booher S, Feuillan P, Kushner H, Leroith D, Cherman N, Bianco P, Wientroub S, Robey PG, Collins MT: Characterization of gsp-mediated growth hormone excess in the context of McCune-Albright syndrome. J Clin Endocrinol Metab 2002;87:5104-5112.

-22 Vallar L, Spada A, Giannattasio G: Altered Gs and adenylate cyclase activity in human GH-secreting pituitary adenomas. Nature 1987;330:566-568.

-23 Kirschner LS, Carney JA, Pack SD, Taymans SE, Giatzakis C, Cho YS, Cho-Chung YS, Stratakis CA: Mutations of the gene encoding the protein kinase A type I- $\alpha$ regulatory subunit in patients with the Carney complex. Nat Genet 2000;26:89-92.

-24 Kovacs K, Horvath E, Thorner MO, Rogol AD: Mammosomatotroph hyperplasia associated with acromegaly and hyperprolactinemia in a patient with the McCuneAlbright syndrome. A histologic, immunocytologic and ultrastructural study of the surgically-removed adenohypophysis. Virchows Arch A Pathol Anat Histopathol 1984; 403:77-86.

-25 Pack SD, Kirschner LS, Pak E, Zhuang Z, Carney JA, Stratakis CA: Genetic and histologic studies of somatomammotropic pituitary tumors in patients with the 'complex of spotty skin pigmentation, myxomas, endocrine overactivity and schwannomas' (Carney complex). J Clin Endocrinol Metab 2000; 85:3860-3865.

26 Sandrini F, Kirschner LS, Bei T, Farmakidis C, Yasufuku-Takano J, Takano K, Prezant TR, Marx SJ, Farrell WE, Clayton RN, Groussin L, Bertherat J, Stratakis CA: PRKAR1A, one of the Carney complex genes, and its locus (17q22-24) are rarely altered in pituitary tumours outside the Carney complex. J Med Genet 2002;39:e78.
27 Zhuang Z, Ezzat SZ, Vortmeyer AO, Weil R, Oldfield EH, Park WS, Pack S, Huang S, Agarwal SK, Guru SC, Manickam P, Debelenko LV, Kester MB, Olufemi SE, Heppner C, Crabtree JS, Burns AL, Spiegel AM, Marx SJ, Chandrasekharappa SC, Collins FS, Emmert-Buck MR, Liotta LA, Asa SL, Lubensky IA: Mutations of the MEN1 tumor suppressor gene in pituitary tumors. Cancer Res 1997;57:5446-5451.

28 Carver LA, Bradfield CA: Ligand-dependent interaction of the aryl hydrocarbon receptor with a novel immunophilin homolog in vivo. J Biol Chem 1997;272:11452-11456.

29 Kuzhandaivelu N, Cong YS, Inouye C, Yang WM, Seto E: XAP2, a novel hepatitis B virus $\mathrm{X}$-associated protein that inhibits $\mathrm{X}$ transactivation. Nucleic Acids Res 1996;24:47414750 .

30 Sumanasekera WK, Tien ES, Turpey R, Vanden Heuvel JP, Perdew GH: Evidence that peroxisome proliferator-activated receptor alpha is complexed with the $90-\mathrm{kDa}$ heatshock protein and the hepatitis virus $\mathrm{B} X$-associated protein 2. J Biol Chem 2003;278: 4467-4473.

31 Carver LA, LaPres JJ, Jain S, Dunham EE, Bradfield CA: Characterization of the Ah receptor-associated protein, ARA9. J Biol Chem 1998;273:33580-33587.

32 Bell DR, Poland A: Binding of aryl hydrocarbon receptor (AhR) to AhR-interacting protein. The role of hsp90. J Biol Chem 2000; 275:36407-36414.

33 Bolger GB, Peden AH, Steele MR, MacKenzie C, McEwan DG, Wallace DA, Huston E, Baillie GS, Houslay MD: Attenuation of the activity of the cAMP-specific phosphodiesterase PDE4A5 by interaction with the immunophilin XAP2. J Biol Chem 2003;278: 33351-33363.

34 De Oliveira SK, Hoffmeister M, Gambaryan S, Muller-Esterl W, Guimaraes JA, Smolenski AP: Phosphodiesterase 2A forms a complex with the co-chaperone XAP2 and regulates nuclear translocation of the aryl hydrocarbon receptor. J Biol Chem 2007;282: 13656-13663.

35 Oesch-Bartlomowicz B, Huelster A, Wiss O, Antoniou-Lipfert P, Dietrich C, Arand M, Weiss C, Bockamp E, Oesch F: Aryl hydrocarbon receptor activation by cAMP vs. dioxin: divergent signaling pathways. Proc Natl Acad Sci USA 2005;102:9218-9223.
36 Kang BH, Altieri DC: Regulation of survivin stability by the aryl hydrocarbon receptorinteracting protein. J Biol Chem 2006;281: 24721-24727.

37 Lees MJ, Peet DJ, Whitelaw ML: Defining the role for XAP2 in stabilization of the dioxin receptor. J Biol Chem 2003;278:3587835888.

>38 Lin BC, Sullivan R, Lee Y, Moran S, Glover E, Bradfield CA: Deletion of the aryl hydrocarbon receptor-associated protein 9 leads to cardiac malformation and embryonic lethality. J Biol Chem 2007;282:35924-35932.

-39 Soares BS, Eguchi K, Frohman LA: Tumor deletion mapping on chromosome 11q13 in eight families with isolated familial somatotropinoma and in 15 sporadic somatotropinomas. J Clin Endocrinol Metab 2005;90: 6580-6587.

40 Aaltonen LA: Aryl hydrocarbon receptor-interacting protein and acromegaly. Horm Res 2007;68(suppl 5):127-131.

41 Georgitsi M, Karhu A, Winqvist R, Visakorpi T, Waltering K, Vahteristo P, Launonen V, Aaltonen LA: Mutation analysis of aryl hydrocarbon receptor interacting protein (AIP) gene in colorectal, breast, and prostate cancers. Br J Cancer 2007;96:352-356.

42 Daly AF, Jaffrain-Rea ML, Ciccarelli A, Valdes-Socin H, Rohmer V, Tamburrano G, Borson-Chazot C, Estour B, Ciccarelli E, Brue T, Ferolla P, Emy P, Colao A, De Menis E, Lecomte P, Penfornis F, Delemer B, Bertherat J, Wemeau JL, De Herder W, Archambeaud F, Stevenaert A, Calender A, Murat A, Cavagnini F, Beckers A: Clinical characterization of familial isolated pituitary adenomas. J Clin Endocrinol Metab 2006;91:33163323.

$\checkmark 43$ Digiovanni R, Serra S, Ezzat S, Asa SL: AIP mutations are not identified in patients with sporadic pituitary adenomas. Endocr Pathol 2007;18:76-78.

44 Yu R, Bonert V, Saporta I, Raffel LJ, Melmed S: Aryl hydrocarbon receptor interacting protein variants in sporadic pituitary adenomas. J Clin Endocrinol Metab 2006;91:51265129.

45 Tamburrano G, Jaffrain-Rea ML, Grossi A, Lise A, Bulletta C: Familial acromegaly. Apropos of a case. Review of the literature (in French). Ann Endocrinol (Paris) 1992;53: 201-207. 